\title{
Alternative substrates and controlled-release fertilizer in the production of yellow passion fruit seedlings
}

\author{
Paulo Sérgio Braña Muniz' ${ }^{\mathbb{D}}$, Romeu de Carvalho Andrade Neto ${ }^{2 *} \mathbb{C}$, Aureny Maria Pereira Lunz ${ }^{2}$ [D, \\ Ueliton Oliveira de Almeida'D, James Maciel de Araújo' (D) \\ Federal University of Acre, Rio Branco, Brasil \\ ${ }^{2}$ Embrapa Acre, Rio Branco, Brasil \\ *Corresponding author, e-mail: romeu.andrade@embrapa.br
}

\begin{abstract}
There are many residues that can be used for agriculture, especially as a substrate. However, it is often necessary to fertilize the growing media so that the seedlings can be produced with quality. The objective of this study was to evaluate the use of alternative and commercial substrates associated with different controlled-release fertilizer levels in producing yellow passion fruit seedlings. The experiment was conducted at the Embrapa Acre seedling nursery, with $50 \%$ luminosity. We used a randomized block experimental design in a $5 \times 3$ factorial scheme with 15 treatments, 4 replicates, and 10 plants per plot. The treatments consisted of five controlledrelease fertilizer levels $\left(0 \mathrm{~kg} \mathrm{~m}^{-3}, 3 \mathrm{~kg} \mathrm{~m}^{-3}, 6 \mathrm{~kg} \mathrm{~m}^{-3}, 9 \mathrm{~kg} \mathrm{~m}^{-3}\right.$, and $\left.12 \mathrm{~kg} \mathrm{~m}^{-3}\right)$ combined with lumps of acerola fruits $(\mathrm{LAF})$, Brazil nut peel (BNP), and commercial (CS) substrates. The evaluated variables were seed height, stem diameter, number of leaves, shoot dry mass (SDM), root dry mass (RDM), total dry mass (TDM), and seedling quality index (SQI). Use of the alternative lumps of acerola fruit (LAF) substrate associated with the $10 \mathrm{~kg} \mathrm{~m}^{-3}$ level of controlled-release fertilizer promoted the best results. BNP has potential for use as a substrate for passion fruit seedlings, however adjustments are necessary to achieve an adequate composition.
\end{abstract}

Keywords: organic waste, Passiflora edulis, plant nutrition

\section{Introduction}

There are numerous processing agroindustries in the Brazil, which constantly and increasingly generate organic residues, and whose inadequate disposal can become a problem in the environment.

One of the most attractive alternatives to the use of these residues is its application in the agricultural environment, for example in formulating substrates for seedling production (Silva-Matos et al., 2016; Kratz et al., 2013). Thus, studies on the use of alternative waste for seedling production are very important, since the cost of commercial substrates can be reduced, the environment can be preserved and sustainability is guaranteed. Several authors have shown that commercial substrates may be replaced by alternative substrates (Meneghelli ef al. 2017; Silva-Matos et al., 2016; Albano et al., 2017; Barros et al., 2013; Boechat et al., 2010; Serrano et al., 2006).

One of the most important requirements for producing quality seedlings is using a substrate which contains physical, chemical and biological characteristics that are adequate for the seedlings' growth and development, being free from phytopathogenic propagules and aggressive weeds (Hartmann et al., 2011 ). Although some substrates contain a significant amount of nutrients, they are often not sufficient to promote adequate growth and vigor of the seedlings. Therefore, frequent fertilization is necessary, which ensures better seedling development and establishment in the field.

When fertilization is practiced, it is required that the fertilizers be parceled out in order to synchronize the plant requirement with the availability of the nutrients. However, this practice, can increase seedling production costs when using conventional fertilizers (Serrano et al., 2012). Thus, one of the alternatives to reduce the needs of these cover fertilizations is to use controlled-release fertilizer, since its application occurs only once in the 
substrate preparation. These fertilizers are known to be important to have the advantage of increasing fertilizer efficiency and manpower, while minimizing nutrient losses by leaching and volatilization.

Research on substrates for passion fruit seedlings has been focused on the combination of substrates, especially manures, soil and commercial substrates (Serrano et al., 2012; Barros et al., 2013;). However, research has been done with alternative substrates from sugar cane residues (Serrano et al., 2006), sawdust biochar (Barros et al., 2017), sewage sludge (Boechat et al., 2013), and decomposed buriti stem (Silva-Matos et al., 2016). Regarding the production and use of substrates from lumps of acerola and Brazil nut peels, no studies have been found in the literature.

There are few studies in the literature related to alternative substrates associated with controlled-release fertilizer for passion fruit seedlings. Thus, the objective of this work was to evaluate the use of agroindustry residues for formulating alternative substrates associated with controlled-release fertilizer levels in producing yellow passion fruit seedlings.

\section{Material and Methods}

The experiment was installed and conducted from October 2016 to January 2017 at the Embrapa Acre, located in the municipality of Rio Branco, Acre state, with the coordinates $10^{\circ} 1$ ' $30^{\prime \prime} \mathrm{S}$ and $67^{\circ} 42^{\prime} 18^{\prime \prime} \mathrm{W}$, at an altitude of approximately $160 \mathrm{~m}$. The climate of the region is hot and humid, classified as Awi according to the Köppen classification, with an annual average temperature of $24.5^{\circ} \mathrm{C}$, relative humidity of $84 \%$ and rainfall between 1,700 and $2,400 \mathrm{~mm}$ per year. Temperature and relative humidity inside the greenhouse were recorded using a AK 174 model data logger (Table 1).

Table 1. Maximum, minimum, and average temperatures and relative humidity registered inside the nursery during the conduction of the experiment.

\begin{tabular}{cccc}
\hline \multicolumn{3}{c}{ Temperature $\left({ }^{\circ} \mathrm{C}\right)$} & \multicolumn{2}{c}{ Relative humidity (\%) } \\
\cline { 1 - 3 } maximum & minimum & average & 88.9 \\
\cline { 1 - 3 } 30.4 & 23.2 & 26.8 & \\
\hline
\end{tabular}

Waste obtained from local agro-industries arranged in the solid waste treatment unit (UTRE-Rio Branco) was used to produce the substrates, consisting of: lumps of acerola fruits (Malpighia emarginata) without undergoing a composting process; and Brazil nut (Bertholletia excelsa) peels decomposed in the open for two years. All substrates were previously sterilized for $20 \mathrm{~min}$, at $1 \mathrm{~atm}$ and $121{ }^{\circ} \mathrm{C}$. After grinding, samples from each waste and of the commercial substrate were collected to be sent to the laboratory of the Agronomic Institute of
Campinas (IAC), located in Campinas, SP, Brazil, in order to perform the chemical, physical, and physical-chemical analyzes (Table 2). The chemical and physical analyses of each substrate determined the nitrogen $(N)$ contents by the Kjedahl method, phosphorus (P), potassium (K), calcium (Ca), magnesium (Mg), sulfur (S), copper (Cu), iron (Fe), manganese ( $\mathrm{Mn})$, and zinc ( $\mathrm{Zn}$ ) contents by the nitric-perchloric extraction and determination method (ICP-OES), organic carbon (C. Org.) by the WalkleyBlack method, $\mathrm{pH}$ in $\mathrm{H}_{2} \mathrm{O} 1: 1.5$, and humidity in forced circulation air oven at $65^{\circ} \mathrm{C}$ until reaching constant mass.

The physical-chemical and physical analyses determined the electrical conductivity (EC), moisture at $65^{\circ} \mathrm{C}$ and the cation exchange capacity (CEC) by the method described in the Normative Instruction IN 17 of May $21^{\text {st }} 2007$ of the Ministry of Agriculture, Livestock And Food Supply (MAPA, 2007), as well as the moist and dry densities and water retention capacity (WRC 10) by the tension table method at $10 \mathrm{~cm}$ of water column (10KPa) according to MAPA Normative Instruction IN no. 31 of October 23rd 2008 (MAPA, 2008).

Table 2. $\mathrm{pH}$, organic carbono $(\mathrm{OC})$, nitrogen $(\mathrm{N})$, phosphorus $(\mathrm{P})$, potassium (K), calcium (Ca), magnesium (Mg), Sulfur (S), Iron (Fe), Manganese (Mn), Boron (B), Copper (Cu), Zinc (Zn), moisture, $\mathrm{C} / \mathrm{N}$ ratio, electrical conductivity (EC), Moist Density, Dry Density, water retention capacity (WRC) and cation exchange capacity (CEC) of the alternative and commercial substrates obtained from the agroindustrial waste from the Solid Waste Treatment Unit of Rio Branco (UTRE). Rio Branco - AC, Brazil, 2017.

\begin{tabular}{|c|c|c|c|c|}
\hline $\begin{array}{c}\text { Element/ } \\
\text { Concentration }\end{array}$ & Unit & LAF & BNP & CS \\
\hline $\mathrm{pH}$ & - & 6.3 & 4.6 & 5.4 \\
\hline C.Org. & $\mathrm{g} \mathrm{kg}^{-1}$ & 374.3 & 300.2 & 154.3 \\
\hline $\mathrm{N}$ & $\mathrm{g} \mathrm{kg}^{-1}$ & 22.1 & 10.6 & 3.3 \\
\hline$P$ & $\mathrm{~g} \mathrm{~kg}^{-1}$ & 1.7 & 0.9 & 2.1 \\
\hline K & $\mathrm{g} \mathrm{kg}^{-1}$ & 9.1 & 1.8 & 2.7 \\
\hline $\mathrm{Ca}$ & $\mathrm{g} \mathrm{kg}^{-1}$ & 12.8 & 15.9 & 8.8 \\
\hline$M g$ & $\mathrm{~g} \mathrm{~kg}^{-1}$ & 1.8 & 2.3 & 1.9 \\
\hline$S$ & $\mathrm{~g} \mathrm{~kg}^{-1}$ & 0.9 & 0.8 & 2.1 \\
\hline $\mathrm{Fe}$ & $\mathrm{mg} \mathrm{kg}^{-1}$ & $1,600.0$ & $11,400.0$ & $4,500.0$ \\
\hline$M n$ & $\mathrm{mg} \mathrm{kg}^{-1}$ & 40 & 267 & 84.5 \\
\hline B & $\mathrm{mg} \mathrm{kg}^{-1}$ & 10.7 & 27.6 & 7.7 \\
\hline $\mathrm{Cu}$ & $\mathrm{mg} \mathrm{kg}^{-1}$ & 10.6 & 23.3 & 6.7 \\
\hline Zn & $\mathrm{mg} \mathrm{kg}^{-1}$ & 18.9 & 38.6 & 15.7 \\
\hline Moisture & $\%$ & 9.2 & 52 & 25.2 \\
\hline $\mathrm{C} / \mathrm{N}$ ratio & $\%$ & 17 & 28.4 & 47.4 \\
\hline EC & $\left(\mathrm{dS} \mathrm{m}^{-1}\right)$ & 0.5 & 0.1 & 1.1 \\
\hline Moist Density & $\left(\mathrm{kg} \mathrm{m}^{-3}\right)$ & 265.8 & 573.1 & 508.9 \\
\hline Dry Density IN 17 & $\left(\mathrm{~kg} \mathrm{~m}^{-3}\right)$ & 241.5 & 275 & 380.8 \\
\hline WRC $10^{3}$ & $(\% \vee / v)$ & 73.6 & 75.3 & 44.4 \\
\hline WRC $10^{3}$ & $(\% \mathrm{~m} / \mathrm{m})$ & 239.1 & 274.6 & 262.3 \\
\hline $\mathrm{CEC}^{4}$ & $\left(\mathrm{mmol}_{\mathrm{c}} \mathrm{kg}^{-1}\right)$ & 485.8 & 666.7 & 627.4 \\
\hline CEC $^{4}$ & $\left(\mathrm{mmol}_{\mathrm{c}} \mathrm{dm}^{-3}\right)$ & 129.1 & 382.1 & 319.3 \\
\hline
\end{tabular}

The experimental design was randomized block with three replicates and 10 plants per plot in a $3 \times 5$ 
factorial scheme with three substrates (lumps of acerola fruits (LAF), Brazil nut peel (BNP), and commercial TropstratV9 mix $\mathrm{SLAB}^{\circledR}(\mathrm{CS})$ ) and five controlled-release fertilizer doses $\left(0.0,3.0,6.0,9.0\right.$ and $\left.12.0 \mathrm{~kg} \mathrm{~m}^{-3}\right)$ mixed with the substrate. The fertilizer doses were defined according to Mendonça et al. (2007).

The controlled-release fertilizer used was Osmocote ${ }^{\circledR}$ (15-9-12), with macro and micronutrients (Mg 1.3, S 6, Cu 0.05, Fe 0.46, Mn 0.06, and Mo 0.02), with a release period of five to six months (5-6 M).

The essay was conducted inside the nursery with $50 \%$ shading and the containers were suspended from the ground, placed on the benches at a height of $80 \mathrm{~cm}$ and made of metal. Transparent polyethylene containers with volumetric capacity of $300 \mathrm{~mL}$ were used and two yellow passion fruit seeds (BRS Gigante Amarelo cultivar) were sown per container. Thinning was performed after first definitive leaf emerged, leaving one plant per container.

A micro-sprinkler irrigation system was used to maintain the substrates at $75 \%$ of field capacity. Manual weeding was conducted monthly for weed control.

The following biometric characteristics were evaluated at 65 days after sowing: number of leaves, by direct count of totally open leaves; plant height $(\mathrm{cm})$, measured by a graduated ruler in centimeters from the base of the substrate until the insertion of the last leaf; stem diameter $(\mathrm{mm})$, determined at $5 \mathrm{~cm}$ from the collar using a digital caliper, and plant height $(\mathrm{cm})$ and stem diameter $(\mathrm{mm})$ ratio.

After the biometric evaluations, the parts of the seedlings were separated into shoots and roots to determine the shoot dry mass (g), root dry mass (g), and total dry mass ( $\mathrm{g}$ ) after drying in a forced ventilation oven at $70^{\circ} \mathrm{C}$ until reaching constant mass.

The seedling quality index (SQI) was determined as a function of plant height (PH), stem diameter (SD), shoot dry mass (SDM), root dry mass (RDM), and total dry

$S Q \mid=$ TDM

$$
(\mathrm{PH}(\mathrm{cm}) / \mathrm{SD}(\mathrm{mm}))+(\mathrm{SDM}(\mathrm{g}) / \operatorname{RDM}(\mathrm{g}))
$$

mass (TDM) using the formula:

Data were submitted to analysis of variance (ANOVA). The Tukey test was applied for the qualitative factor and regression analysis was performed for the quantitative factor, both at $5 \%$ probability.

\section{Results and Discussion}

There was a significant effect ( $p<0.05$ ) for both isolated factors and for interaction between them in relation to all variables (Table 3).

The lumps of acerola fruit substrate were superior to Brazil nut peel substrate for all characteristics of passion fruit seedlings, as well as being superior or equivalent to commercial substrate, except for PH/SD and SDM (Table 4).

Table 3. Analysis of variance for plant height (PH), stem diameter (SD), height plant to stem diameter ratio (PH/SD), number of leaves (NL), shoot dry mass (SDM), root dry mass (RDM), total dry mass (TDM) and seedling quality index (SQI) of yellow passion fruit seedlings (Passiflora edulis) in response to alternative substrates (S) and controlled-release fertilizer levels (L).

\begin{tabular}{|c|c|c|c|c|c|c|c|c|}
\hline \multicolumn{2}{|c|}{ Source } & Substrate (S) & Levels (L) & $S \times L$ & Block & Residual & Mean & CV (\%) \\
\hline \multicolumn{2}{|c|}{ d.f. } & 2 & 4 & 8 & 2 & 28 & - & - \\
\hline \multirow{8}{*}{ 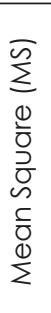 } & $\mathrm{PH}$ & $58.41^{*}$ & $862.24^{*}$ & $82.59 *$ & $1.71^{\mathrm{ns}}$ & 3.28 & 15.58 & 11.63 \\
\hline & SD & $2.83^{*}$ & $7.60 *$ & $0.20^{*}$ & $0.01^{\text {ns }}$ & 0.02 & 2.69 & 5.82 \\
\hline & $\mathrm{PH} / \mathrm{SD}$ & $89.65^{*}$ & $269.77^{*}$ & $31.48 *$ & $1.42^{\mathrm{ns}}$ & 1.33 & 5.26 & 8.25 \\
\hline & $N L$ & $8.64^{*}$ & $54.70^{*}$ & $4.99 *$ & $0.05^{\mathrm{ns}}$ & 0.16 & 8.88 & 4.53 \\
\hline & SDM & $236.90^{*}$ & $632.75^{*}$ & $45.78^{*}$ & $1.11^{\mathrm{ns}}$ & 1.85 & 11.55 & 11.87 \\
\hline & RDM & $6.51^{*}$ & $30.83^{*}$ & $1.02 *$ & $0.06^{n s}$ & 0.08 & 3.26 & 8.96 \\
\hline & TDM & $311.54^{*}$ & $933.95^{*}$ & $56.72^{*}$ & $1.69^{\mathrm{ns}}$ & 2.45 & 14.81 & 10.53 \\
\hline & SQI & 1.83* & $12.48^{*}$ & $0.31^{*}$ & $0.01^{\mathrm{ns}}$ & 0.06 & 2.20 & 9.63 \\
\hline
\end{tabular}

*Significance at 5\%; ns not significant according to the F-test; $\mathrm{CV}=$ coefficient of variation.

Table 4. Plant height (PH), stem diameter (SD), plant height and stem diameter ratio (PH/SD), number of leaves (NL), shoot dry mass (SDM), root dry mass (RDM), total dry mass (TDM) and seedling quality index (SQI) of yellow passion fruit seedlings (Passiflora edulis) in response to alternative substrates (S) and controlled-release fertilizer levels (L).

\begin{tabular}{|c|c|c|c|c|c|c|c|c|}
\hline Substrates* & $\mathrm{PH}(\mathrm{cm})$ & $\mathrm{SD}(\mathrm{mm})$ & $\mathrm{PH} / \mathrm{SD}$ & $\mathrm{NL}$ & $\operatorname{SDM}\left(\mathrm{g} \mathrm{pl}^{-1}\right)$ & $\operatorname{RDM}\left(\mathrm{g} \mathrm{pl}^{-1}\right)$ & TDM $\left(\mathrm{g} \mathrm{pl}^{-1}\right)$ & SQI \\
\hline LAF & $18.56 \mathrm{a}$ & $3.04 \mathrm{a}$ & $5.44 b$ & $9.70 \mathrm{a}$ & $1.32 \mathrm{~b}$ & $0.38 \mathrm{a}$ & $1.70 \mathrm{a}$ & $1.77 \mathrm{a}$ \\
\hline BNP & $9.94 \mathrm{~b}$ & $2.21 \mathrm{C}$ & $4.40 \mathrm{C}$ & $8.20 \mathrm{c}$ & $0.70 \mathrm{c}$ & $0.25 c$ & $0.96 b$ & $1.30 \mathrm{~b}$ \\
\hline SC & $18.24 \mathrm{a}$ & $2.83 \mathrm{~b}$ & $5.91 \mathrm{a}$ & $8.75 \mathrm{~b}$ & $1.45 \mathrm{a}$ & $0.34 \mathrm{~b}$ & $1.79 \mathrm{a}$ & $1.64 \mathrm{a}$ \\
\hline CV (\%) & 11.63 & 5.82 & 8.25 & 4.53 & 11.87 & 8.96 & 10.53 & 9.63 \\
\hline
\end{tabular}

LAF: lumps of acerola fruits; BNP: Brazil nut peel; CS: commercial substrate.

Means followed by the same letter do not differ by the Tukey test $(p>0.05)$.

The plant height was adjusted to the linear regression model for the different substrates, observing an increase in the level of up to $12 \mathrm{~kg}$ of controlledrelease fertilizer per $\mathrm{m}^{3}$ of substrate (Figure 1). The LAF 
substrate provided greater seedling height $(35.27 \mathrm{~cm})$ at $12 \mathrm{~kg} \mathrm{~m}^{-3}$ of controlled-release fertilizer. The plant height increased as the fertilizer doses increased and with 12 $\mathrm{kg}$ of fertilizer, and the seedlings produced using the LAF substrate reached $19.6 \%$ and $152 \%$ higher than the plants produced using the CS and BNP substrates, respectively. Higher concentration of $\mathrm{N}$, narrower $\mathrm{C} / \mathrm{N}$ ratio, and lower moist density of LAF, besides maintaining the WRC (Table 2), may have been responsible for the higher plant height obtained, since the first gives greater plant growth and the second, being inversely proportional to porosity, may have provided a better temperature condition, moisture and aeration so that the fertilizer could be released.

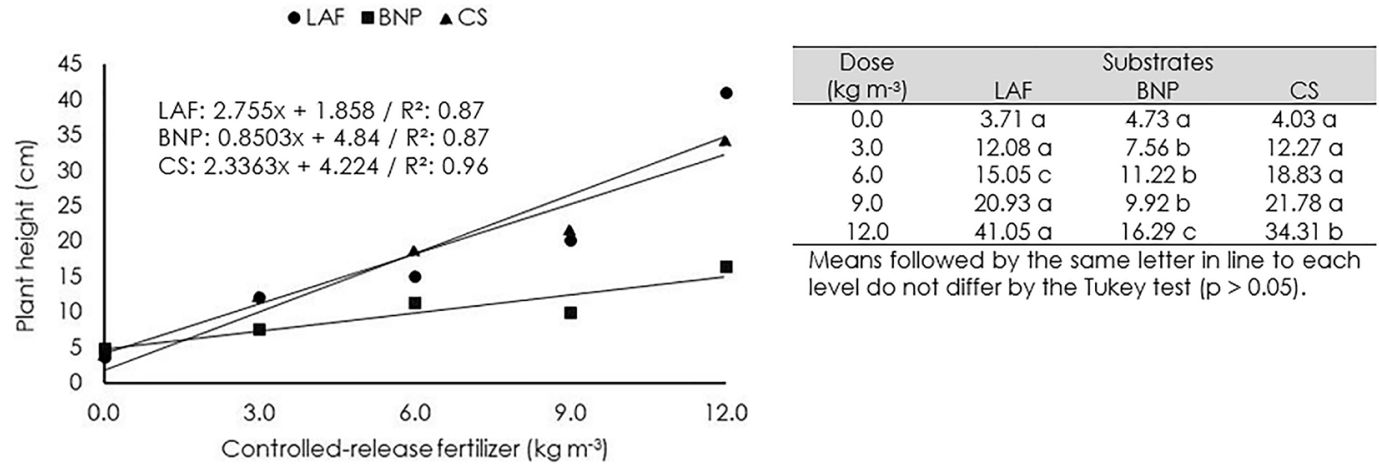

Figure 1. Plant Height $(\mathrm{cm})$ of the yellow passion fruit seedling in function of the substrates and controlled-release fertilizer levels. LAF: Iumps of acerola fruits; BNP: Brazil nut peel; CS: commercial substrate.

The plant height values determined in this study are higher than several studies developed on the same theme (Boechat et al., 2010). Silva-Matos et al. (2016) showed better results for plant height of passion fruit seedlings in substrates composed of soil and sand 1:1 $(40 \%)+$ decomposed buriti stem $(60 \%)$, soil and sand $1: 1$ $(60 \%)+$ decomposed buriti stem $(40 \%)+0.5 \mathrm{mg} \mathrm{dm}^{-3}$ of B and sand $1: 1(80 \%)+$ decomposed buriti stem $(20 \%)+0.5$ $\mathrm{mg} \mathrm{dm} \mathrm{m}^{-3}$ of $\mathrm{B}$.

For stem diameter, the linear regression model was adjusted for LAF and BNP substrates as a function of the controlled-release fertilizer levels. The quadratic regression model was adjusted for the CS substrate (Figure 2). The seedlings produced in the CS at $11.3 \mathrm{~kg} \mathrm{~m}^{-3}$ of controlled-release fertilizer showed $3.74 \mathrm{~mm}$ of diameter.

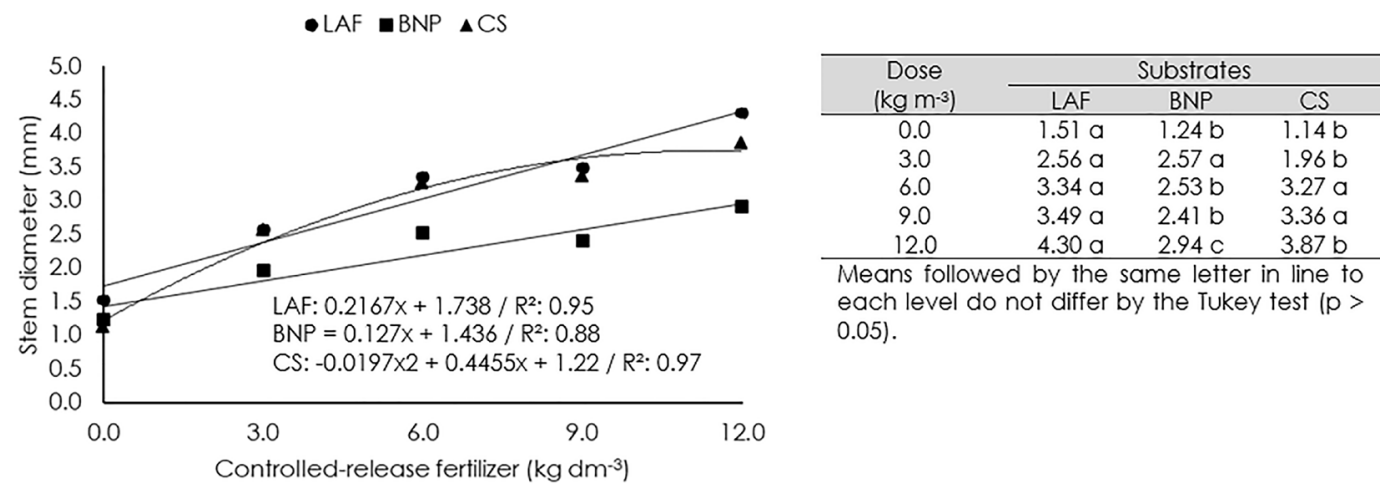

Figure 2. Stem diameter ( $\mathrm{mm}$ ) of yellow passion fruit seedlings in function of the substrates and controlledrelease fertilizer levels. LAF: Iumps of acerola fruits; BNP: Brazil nut peel; CS: commercial substrate.

The stem diameter of seedlings produced on LAF with $12 \mathrm{~kg}$ of controlled-release fertilizer is larger than those evaluated by Serrano et al. (2006), by combining controlled-release fertilizer and different substrate compositions.

Seedlings produced using LAF and CS substrates containing at least $6 \mathrm{~kg}$ of fertilizer presented a stem diameter close to the values determined by Barros et al. (2017), after studying alternative substrates, and superior to those determined by Boechat et al. (2010) when combining substrates and conventional mineral fertilization.

Regression analysis applied to the data related to the plant height and stem diameter ratio (PH/SD) of yellow passion fruit seedlings resulted in better linear adjustments for all evaluated substrates (Figure 3).

The PH/SD parameter, known as sturdiness quotient (SQ), is recognized as one of the main quality standard indicators and expresses the vigour and robustness of the seedling (Takoutsing et al., 2014). In 
passion fruit it has not been common to determine this parameter, perhaps because the main index considered is $S Q I$, which in its calculation already considers the $S Q$. Anyway, a lower PH/SD ratio contributes to increase SQI, which leads us to infer that seedlings with a lower $\mathrm{PH} /$ SD tend to be of better quality than those with a higher $\mathrm{PH} / \mathrm{SD}$. As well as for forest species, whose PH/SD can vary depending on several factors, such as substrate, fertilization, seedling age (Faria et al., 2019), for passion fruit this index certainly varies depending on factors of seedling production and the region. Therefore, because it is easy to measure and has the advantage of including two non-destructive variables, determining a $\mathrm{PH} / \mathrm{SD}$ standard for passion fruit is necessary.

The controlled-release fertilizer doses influenced the number of leaves of yellow passion fruit seedlings following a quadratic model of regression for all the substrates (Figure 4), so that the maximum plant height obtained was $12.3 \mathrm{~cm}$ at the dose of $11.91 \mathrm{~kg} \mathrm{~m}^{-3}$ of controlled-release fertilizer.

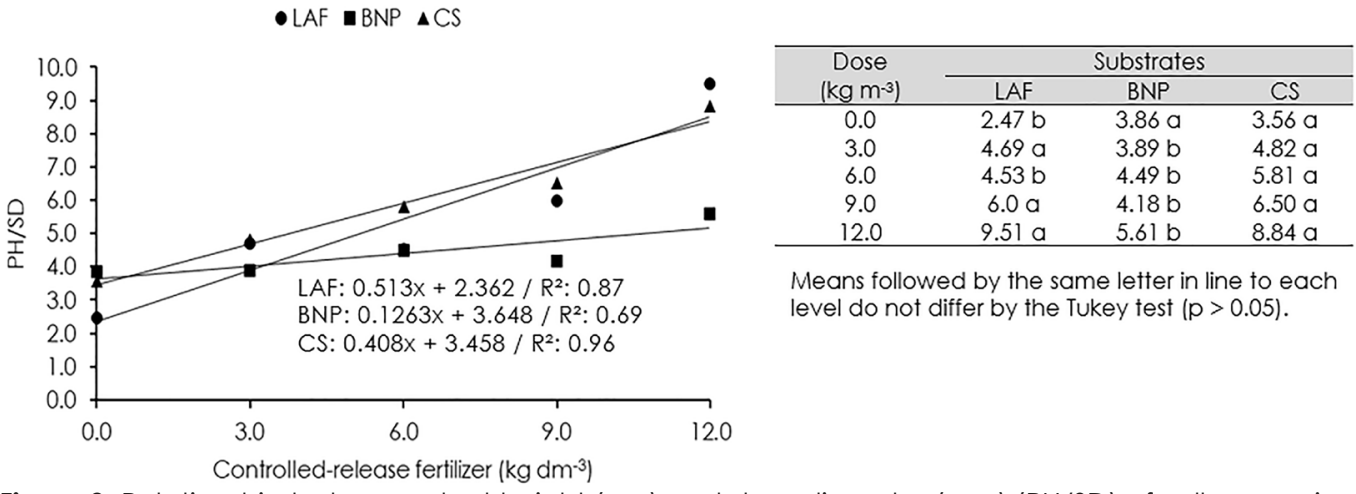

Figure 3. Relationship between plant height $(\mathrm{cm})$ and stem diameter $(\mathrm{mm})(\mathrm{PH} / \mathrm{SD})$ of yellow passion fruit seedlings in function of the substrates and controlled-release fertilizer levels. LAF: lumps of acerola fruits; BNP: Brazil nut peel; CS: commercial substrate.

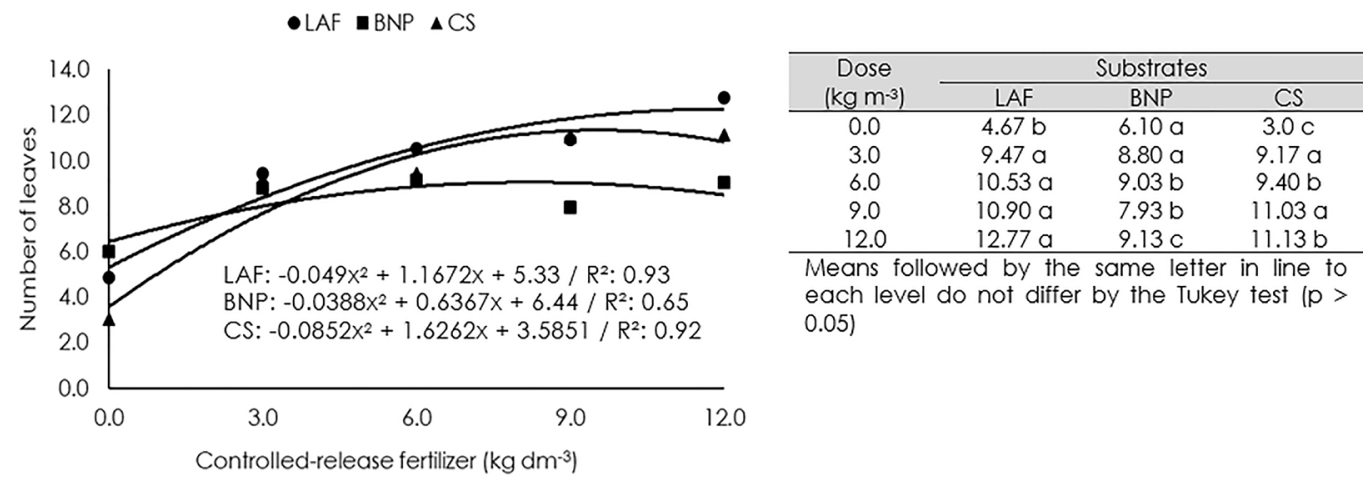

Figure 4. Number of leaves (NL) of the yellow passion fruit seedlings in function of the substrates and controlled-release fertilizer levels. LAF: lumps of acerola fruits; BNP: Brazil nut peel; CS: commercial substrate.

Several studies have shown that the number of passion fruitleaves is influenced by the nutrition and substrate used (Andrade et al., 2018; Miyake et al., 2016; Fey et al., 2010; Sousa et al., 2011). It was possible to obtain passion fruit seedlings with larger number of leaves starting from $3 \mathrm{~kg}$ of controlled-release fertilizer incorporated with LAF, BNP and CS substrates than Cavalcante et al. (2019) when producing seedlings with different organic compounds and by Barros et al. (2017) after studying commercial substrate combinations with activated biochar and sawdust biochar, all supplied with $225 \mathrm{~g}$ Basacote ${ }^{\circledR} 6 \mathrm{M}$ and $225 \mathrm{~g}$ Basacote $^{\circledR} 3 \mathrm{M}$ for $150 \mathrm{~L}$ of substrate (equivalente to $3 \mathrm{~kg}$ $\mathrm{m}^{-3}$ ) and $600 \mathrm{~g} \mathrm{FH}$ Eucalipto Heringer ${ }^{\circledR}$. A larger number of leaves reflects in a greater amount of photoassimilates that will be translocated to different parts of the plant, thereby influencing its growth and development.

It was possible to observe that the shoot dry mass (SDM), root dry mass (RDM) and total dry mass (TDM) values were adjusted to the linear regression model for all substrates in function of the controlled-release fertilizer levels (Figures 5, 6 and 7, respectively).

For the SDM, CS was superior to the other substrates from $3 \mathrm{~kg} \mathrm{~m}^{-3}$, not differing from LAF in the dose of $12 \mathrm{~kg} \mathrm{~m}^{-3}$. The LAF substrate with at least $9 \mathrm{~kg}$ of fertilizer led the seedlings to have a higher RDM. Regarding the TDM, from $9 \mathrm{~kg} \mathrm{~m}^{-3}$, LAF and CS presented the best results, without differing from each other.

The results for SDM, RDM and TDM presented by LAF and BNP, with $12 \mathrm{~kg} \mathrm{~m}^{-3}$, are superior to Cordeiro et al. (2019) and close to those of Silva-Matos et al. (2016), 
with the exception of RDM. The SDM of the seedlings determined in this work exceeds the values determined by Andrade et al. (2018) when evaluating different substrates with and without biofertilizer.

- LAF —BNP $\triangle \mathrm{CS}$

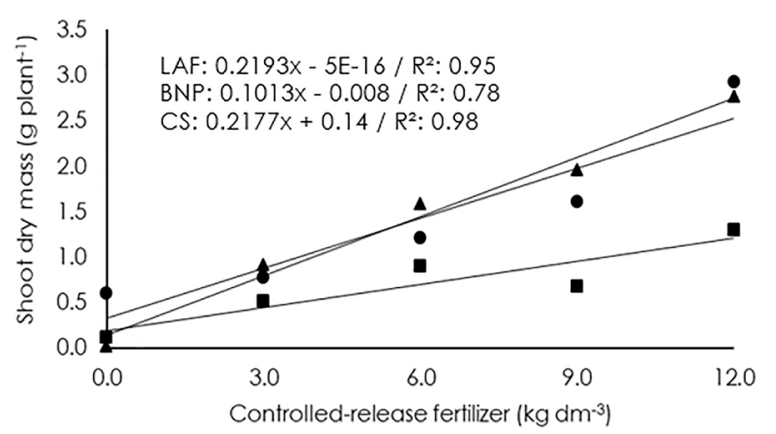

\begin{tabular}{cccc}
\hline Doses & \multicolumn{3}{c}{ Substrates } \\
\cline { 2 - 4 }$\left(\mathrm{kg} \mathrm{m}^{-3}\right)$ & LAF & BNP & CS \\
\hline 0.0 & $0.06 \mathrm{a}$ & $0.12 \mathrm{a}$ & $0.02 \mathrm{a}$ \\
3.0 & $0.77 \mathrm{~b}$ & $0.51 \mathrm{ab}$ & $0.91 \mathrm{a}$ \\
6.0 & $1.21 \mathrm{~b}$ & $0.90 \mathrm{c}$ & $1.58 \mathrm{a}$ \\
9.0 & $1.61 \mathrm{~b}$ & $0.68 \mathrm{c}$ & $1.96 \mathrm{a}$ \\
12.0 & $2.93 \mathrm{a}$ & $1.30 \mathrm{~b}$ & $2.76 \mathrm{a}$ \\
\hline Means followed by the same letter in line to \\
each level do not differ by the Tukey test (p > \\
0.05)
\end{tabular}

$0.05)$

Figure 5. Shoot dry mass (SDM) of yellow passion fruit seedlings in function of substrates and controlledrelease fertilizer levels. LAF: Iumps of acerola fruits; BNP: Brazil nut peel; CS: commercial substrate.

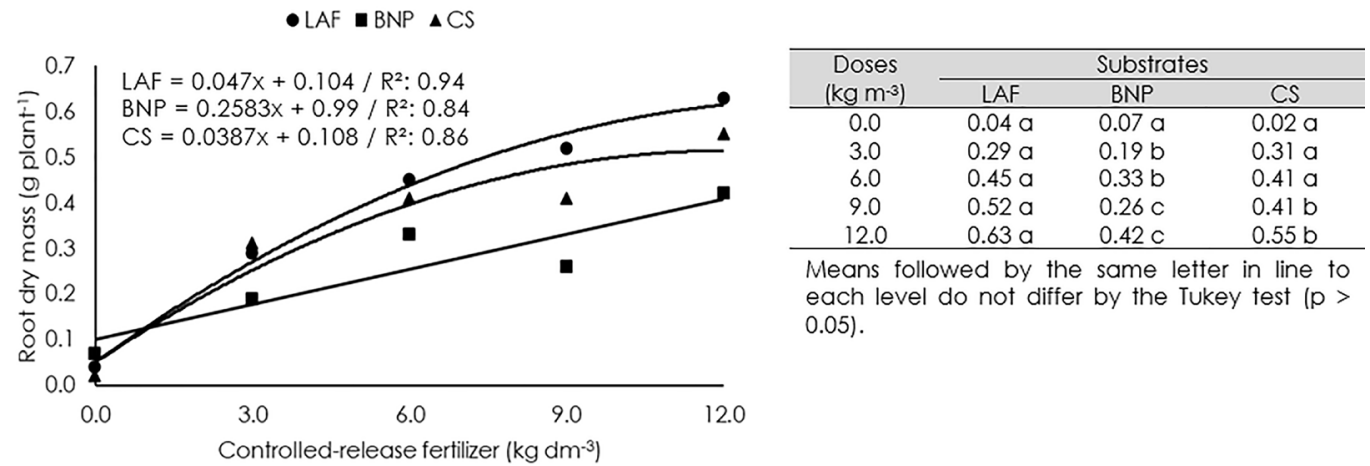

Figure 6. Root dry mass (RDM) (g) of yellow passion fruit seedlings in function of the substrates and controlled-release fertilizer levels. LAF: Iumps of acerola fruits; BNP: Brazil nut peel; CS: commercial substrate.

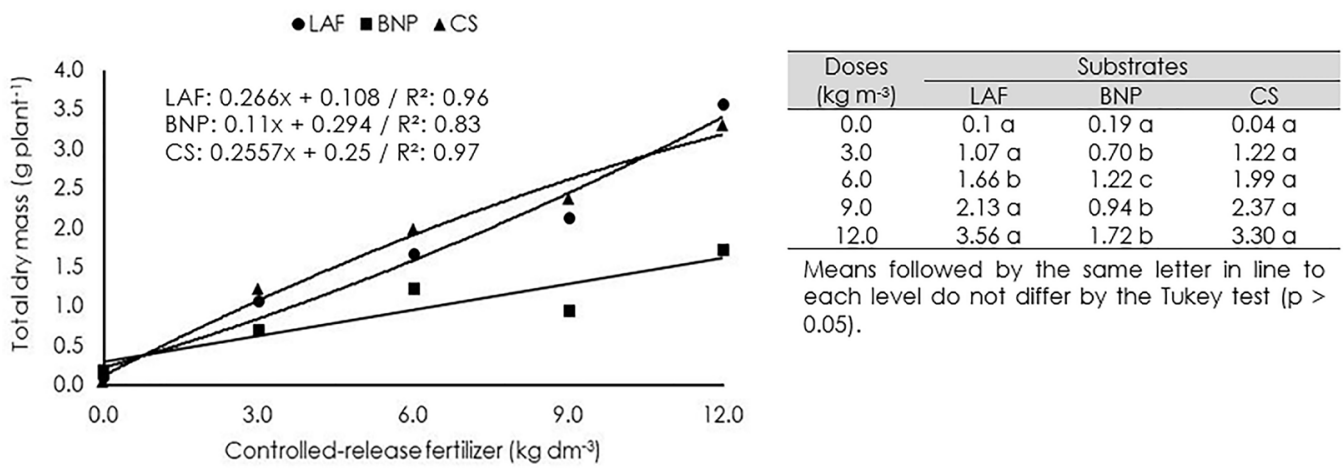

Figure 7. Total dry mass (g) (TDM) of yellow passion fruit seedlings in function of the substrates and controlled-release fertilizer levels. LAF: lumps of acerola fruits; BNP: Brazil nut peel; CS: commercial substrate.

The better performance of the seedlings in relation to the SDM, RDM and TDM grown on the LAF and BNP substrates fertilized with controlled-release fertilizer, can be explained by the chemical composition of these substrates, especially the $\mathrm{pH}$ that remained in a range where the nutrients could be made available to the seedlings (Table 2), including those provided by the controlled release fertilizer. It is highlighting that the physical and chemical of each substrate explains the differences between treatments regarding the accumulation of dry mass.

The results show that substrates with an adequate amount of nutrients are essential for the accumulation of biomass, since essential nutritional deficiencies compromise the metabolism of plants and reduce the growth of seedlings (Zavistanovicz et al., 2017). The treatments with the largest accumulations of dry mass were those with the highest number of leaves, because the greater the number of leaves, the greater the carbon fixation and consequent mass accumulation.

Regarding the SQI, the controlled-release fertilizer levels adjusted to the quadratic regression model for all substrates (Figure 8). At the level of 9.58 for LAF, 12.00 for BNP and 10.17 for CS, the seedlings reached SQI of 0.26 , 
0.18 and of 0.24 , respectively.

Seedlings of yellow passion fruit submitted to organic fertilization obtained an index of 0.57 (Andrade et al., 2018) while the index ranged from 0.19 to 0.24 in different substrates (Costa et al., 2018). Yellow passion fruit seedlings grown on alternative substrates and with controlled-release fertilizer presented a SQI of 0.18 to 0.26 (Barros et al., 2017).

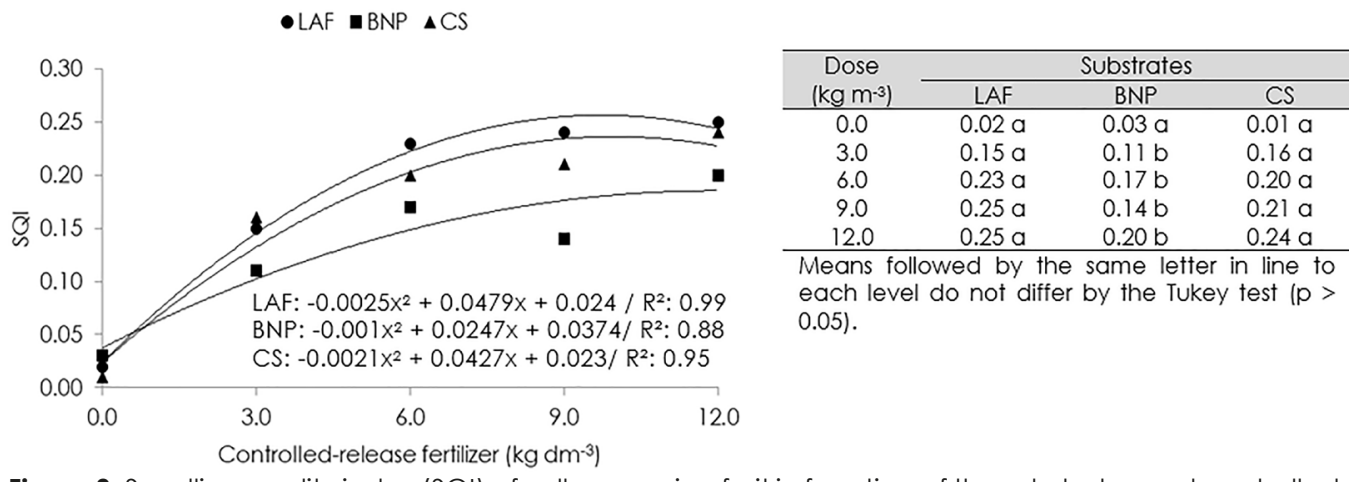

Figure 8. Seedling quality index (SQI) of yellow passion fruit in function of the substrates and controlledrelease fertilizer levels. LAF: lumps of acerola fruits; BNP: Brazil nut peel; CS: commercial substrate.

This index is a good indicator of seedling quality because it combines biometric and plant biomass variables. Although it is reported that plants must have SQI greater than 0.2, this index is variable for passion fruit seedlings depending on the production system adopted.

There is a great diversity of substrates in the literature with quite varied chemical and physical compositions. Substrates in Brazil generally have general indications, whether for fruit or vegetables.

According to Zorzeto et al. (2014), substrates that present good physical characteristics such as apparent, volumetric, and particle densities, porosity, water retention capacity, grain size, and total porosity tend to show better qualitative results for seedling formation. We observed a balance of these physical attributes in the lumps of acerola fruits substrate in this study, which, along with its chemical richness, provided seedlings with better $\operatorname{SDM}(\mathrm{g})$ results.

The production of seedlings using organic residues to produce alternative substrates has increased in nurseries and farms as an alternative to using commercial substrates and has shown significant results in producing passion fruit seedlings (Barros et al., 2013).

For most chemical and physical variables, the substrates used showed values close or higher than those studied by Silva et al. (2018), Silva-Matos et al. (2016) and Serrano et al. (2006). For all substrates evaluated, P, K, Ca, $\mathrm{Mg}, \mathrm{Fe}, \mathrm{Zn}, \mathrm{Mn}$ and $\mathrm{B}$ contents are higher than the values established by Noguera et al. (2003). Regarding the substrates studied by Ramirez \& Pascual-Alex (2010), all the chemical characteristics of substrates evaluated in this study were higher. The best results presented by passion fruit seedlings when produced using LAF substrates can be explained by the composition of this substrate, since the organic carbon, macro and micronutrient contents are higher or even equivalent to the commercial substrate. Moreover, the substrate from the acerola fruit has the advantage of not being composted, unlike commercial substrates which take up to six months (depending on the raw material) to be ready for use.

According to Hartmann et al. (2011), the $\mathrm{pH}$ of the LAF substrate is within the range which may favor nutrient availability to plants. Plant or animal substrates with a pH between 5.5-6.5 have higher availability of primary macronutrients ( $N, P$ and $K$ ) and smaller micronutrients (Munita, 2001), as this hypothesis was confirmed by the analysis (Table 2).

The lower performance of the BNP substrate was probably due to its low $\mathrm{pH}$ (Table 2). Although acidic $\mathrm{pH}$ (below 5.0) is harmful to root membranes and can increase the concentrations of $\mathrm{Al}$ and $\mathrm{Mn}$ in the substrate solution to toxic levels (Silber \& Bar-tal, 2008), the dominant role of $\mathrm{pH}$ with uptake of micronutrients generally implies that absorption is sometimes more affected by the $\mathrm{pH}$ level than by the concentrations of the element. Thus, although the Mn content was high (Maher et al., 2008), no symptoms of toxicity were observed by the plants, probably because it was leachate. One of the strategies to increase the $\mathrm{pH}$ of BNP substrate and, consequently, the availability of nutrients, could be the use of limestone.

LAF had the lowest $\mathrm{C} / \mathrm{N}$ ratio among the substrates and reached adequate maturity ( $C / N<20)$, according to Gavilanes-Terán et al. (2017). However, Mininni et al. (2013) studied different mixing (traditional peat and posidonia composts) in different ratios for tomato and melon seedling production and concluded that all mixtures with a $\mathrm{C}: \mathrm{N}$ ratio ranging from 11.2 to 43.0 were suitable for seedling production. 
According to Kampf (2005), suitable substrates should have a dry density between 200 and $400 \mathrm{~kg} \mathrm{~m}^{-3}$, values that were presented by all substrates used herein. However, this parameter should not be considered in isolation and should be set according to each species. The values in the literature vary widely depending on the species and the substrate, without compromising the quality of the seedling. The values for llex paraguariensis were around $750 \mathrm{~kg} \mathrm{~m}^{-3}$ (Zavistanovicz et al., 2017); substrates formed from the mixture of vermiculite with rice husk for Eugenia dysenterica showed values ranging from $149.6 \mathrm{~kg} \mathrm{~m}^{-3}$ to $168.3 \mathrm{~kg} \mathrm{~m}^{-3}$ (Mota et al., 2018).

Furthermore, the values for Eucalyptus ranged from 121.58 to $381.55 \mathrm{~kg} \mathrm{~m}^{-3}$ (Neres et al., 2019). Even commercial substrates are out of this range, which reinforces the thesis to determine the pattern as a function of each substrate and plant species to be produced. The values for Rendimax Citrus $^{\circledR}$ substrate and Mecplant Citrus ${ }^{\circledR}$ substrate were respectively $255 \mathrm{~kg} \mathrm{~m}^{-3}$ and $213 \mathrm{~kg} \mathrm{~m}^{-3}$ (Schäfer et al., 2008), close to this study. Moreover, the value for Trimix ${ }^{\circledR}$ was $159.4 \mathrm{~kg} \mathrm{~m}^{-3}$ (Mota ef al., 2018), while for Trimix and Bioplant they were between 150 and $200 \mathrm{~kg} \mathrm{~m}^{-3}$ (Braga et al., 2019). Lastly, the values for tropstrato ${ }^{\circledR}$ and vivatto ${ }^{\circledR}$ were $325.76 \mathrm{~kg} \mathrm{~m}^{-3}$ and 360.77 $\mathrm{kg} \mathrm{m}^{-3}$, respectively (Neres et al., 2019).

All substrates showed EC within the acceptable range. However, it is important to note that each species requires an appropriate range. For example, a

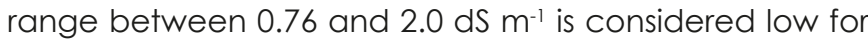
vegetables and therefore suitable to produce vegetable seedlings. In the work developed by Neres et al. (2019), tropstrato ${ }^{\circledR}$, bioplant ${ }^{\circledR}$ and vivatto ${ }^{\circledR}$ commercial substrates

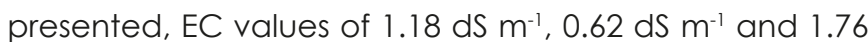
$\mathrm{dS} \mathrm{m}^{-1}$, respectively, all of which are recommended for seedling production in general. According to Cavalcante et al. (2009), passion fruit is sensitive to electrical conductivity, since seeds do not germinate and plants do not grow or produce properly in places where the electrical conductivity of soil saturation extract is greater than $1.3 \mathrm{dS} \mathrm{m}^{-1}$.

It was noticed that the controlled-release fertilizer doses tended to linear regression model for most analyzed substrates and variables, which implies that the doses should have been higher. However, because the fertilizer had controlled release for five to six months and the seedlings were evaluated at two months, there was no synchronization between nutrient release and seedling requirement. Thus, the doses could have been lower and the controlled-release fertilizer had a shorter release time. Perhaps the fertilizer used in this study could be used for seedlings that require a longer stay in the nursery, such as 'tall seedling' widely used in the state of São Paulo as a strategy for dealing with the fruit hardening virus of passion fruit.

Regardless of the substrate used, the need to use a fertilizer to meet the need of seedlings is evident. A substrate with an adequate nutrient content provides adequate growth of plants in the field, thus ensuring their establishment, survival, development and production. Most commercial substrates need nutritional supplementation since they do not contain the essential nutrients for seedling formation (Boechat et al., 2010; Prates et al., 2010).

\section{Conclusions}

The growth of yellow passion fruit seedlings is influenced by alternative substrates and the controlledrelease fertilizer dose.

The LAF and CS substrate combined with controlled-release fertilizer provides the highest quality seedlings for producing yellow passion fruit.

BNP has potential for use as a substrate for passion fruit seedlings, however adjustments are necessary to achieve an adequate composition.

\section{Acknowledgments}

To $\mathrm{CNPq}$ for granting a research scholarship (process: 313552/2017-7) to the second author.

\section{References}

Albano, F.G., Cavalcante, Í.H.L., Machado, J.S., Lacerda, C.F., Silva, E.R., Sousa, H.G. 2017. New substrate containing agroindustrial carnauba residue for production of papaya under foliar fertilization. Revista Brasileira de Engenharia Agrícola e Ambiental 2: 128-133.

Andrade, F.H.A., Alves, A.S., Clemente, M.I.B., Andrade, L.R., Oliveira, D.S., Pereira W.P., Linhares, P.C.A. 2018. Initial Growth of Yellow Passion Fruit Under Organic Fertilization. Journal of Agricultural Science 10: 191-198.

Barros, C.M.B., Müller, M.M.L., Botelho, R.V., Michalovicz, L., Vicensi, M., Nascimento, R. 2013. Substratos com compostos de adubos verdes e biofertilizante via foliar na formação de mudas de maracujazeiro-amarelo. Semina: Ciências Agrarias 34: 2575-2588.

Barros, D.L., Rezende, F.A., Campos, A.T., Maia, C.M.B.F. 2017. Biochar of Sawdust Origin in Passion Fruit Seedling Production. Journal of Agricultural Science 9: 200-207.

Boechat, C.L., Teixeira, A.M., Costa, A.S.V., Souza, A.P.S.B. 2010. Influência de substratos associados à adubação mineral sobre o crescimento inicial de duas cultivares de maracujazeiro-amarelo. Revista Caatinga 23: 19-25.

Boechat, C.L., Teixeira, A.M., Costa, V., Sylvio, A., Rebouças, B.S. 2013. Initial growth of yellow passion fruit seedlings in substrate composed of pulp mill sludge and 
cattle manure. Revista Caatinga 26: 01-08.

Braga, N.C.C., Severiano, E.C., Santos, L.S., Neto, A.R., Rodrigues, T.M., Lima, J.D.P. 2019. Production of sugarcane seedlings pre-sprouted in commercial and alternative substrates with by-products of the sugarcane industry. Semina: Ciências Agrárias 40: 33-48.

Cavalcante, A.G., Araújo, R.C., Cavalcante, A.C.P. Barbosa, A.S., Diniz Neto, M.A., Matos, B.F., Oliveira, D.S., Zuza, J.F.C. 2019. Production of yellow passion fruit seedlings on substrates with different organic compounds. African Journal of Agricultural Research 11: 1089-1091.

Cavalcante, L.F., Sousa, G.G., Gondim, S.C., Figueiredo, F.L., Cavalcante, I.H.L., Diniz, A.A. 2009. Crescimento inicial do maracujazeiro amarelo manejado em dois substrastos irrigados com água salina. Irriga 14: 504-517.

Cordeiro, K.V., Costa, N.A., Andrade, H.A.F., OliveiraNeto, E.D., Rocha, B.R.S., Machado, N.A.F., Albano, F.G., Furtado, M.B., Silva-Matos, R.R.S. 2019. Inclusion of babassu decomposed stem substrates on the pattern of the vegetative growth of passion fruit seedlings. Communications in Soil Science and Plant Analysis 50: $2777-2786$

Costa, F.M., Anjos, G.L., Camilo, G.B.M., Oliveira, U.C., Souza, G.S., Santos, A.R. 2018. Produção de mudas de maracujazeiro amarelo em diferentes composições de substrato e ambiente. Revista de Ciências Agrárias 41: 141-150.

Faria, J.C.T., Lopes, D.A., Lyra, G.B., Melo, H.C., Melo, L.A. 2019. Manejo da densidade de plantas durante a produção de mudas em viveiro. Ciência Florestal 29: 1187-1198.

Fey, R., Zoz, T., Steiner, F., Castagnara, D.D., Ferreira, G. 2010. Crescimento inicial de mudas de maracujazeiro amarelo em função de doses crescentes de superfosfato simples. Revista Brasileira de Ciências Agrária 5: 347-353.

Gavilanes-Terán, I., Jara-Samaniego, J., Idrovo-Novillo, J., Bustamante, M.A., Pérez-Murcia, M.D., Pérez-Espinosa, A., López, M., Paredes, C. 2017. Agroindustrial compost as a peat alternative in the horticultural industry of Ecuador. Journal of Environmental Management 186: 79-87.

Hartmann, H.T., Kester, D.E., Davies Jr., F.T., Geneve, R.L. 2011. Plant propagation: principles and practices. Prentice Hall/ Pearson, New Jersey, USA. 915 p.

Kampf, A.N. 2005. Produção comercial de plantas ornamentais. Editora Rígel, Guaíba, Brazil, 254 p.

Kratz, D., Wendlling, I., Nogueira, A.C., Souza, P.V. 2013. Propriedades físicas e químicas de substratos renováveis. Revista Árvore 376: $1103-113$.

Maher, M., Prasad, M., Raviv, M. 2008. Organic soilless media components. In: Soilless Culture: Theory and practice. Elsevier, San Diego, CA, p. 459-504.

MAPA.Ministério da Agricultura PecuáriaeAbastecimento. 2007. https://www.gov.br/agricultura/<Acesso em 01 Jun. 2020>
MAPA. Ministério da AgriculturaPecuáriae Abastecimento. 2008. https://www.gov.br/agricultura/<Acesso em 01 Jun. 2020>

Mendonça, V., Tosta, M.S., Machado, J. R., Goulart Júnior, S.A.R., Tosta, J.S., Biscaro, G.A. 2007. Fertilizante de liberação lenta na formação de mudas de maracujazeiro 'amarelo'. Ciência e Agrotecnologia 31: 344-348.

Meneghelli, L.A.M., Monaco, P.A.V.L., Haddade, I.R, Meneghelli, C.M., Almeida, K.M. 2017. Agricultural residues as a substrate in the production of eggplant seedlings. Horticultura Brasileira 35: 527-533.

Mininni, C., Bustamante, M., Medina, E., Montesano, F., Paredes, C., Pérez-Espinosa, A., Moral, R., Santamaria, P. 2013. Evaluation of posidonia seaweed-based compost as a substrate for melon and tomato seedling production. Journal of Horticultural Science \& Biotechnology 88: 345351.

Miyake, R.T.M., Takata, W.H.S., Guerra, W.E.X., Forli, F., Narita, N., Creste, J.E. 2016. Effects of potassium fertilization and commercial substrates on development of passion fruit seedlings under greenhouse condition. African Journal of Agricultural Research 11:3720-3727.

Mota, C.S., Silva, F.G., Dornelles, P., Freiberger, M.B., Reis, D.N., Mendes, G.C. 2018. Parameters of physiology, nutrition and quality of eugenia dysenterica dc seedlings grown in organic substrates from the agricultural industry. Journal of Agricultural Science 10: 73-84.

Munita, J. 2001. Características y clasificación de los suelos. Sociedad Química y Minera de Chile S.A, Santiago, Chile. $1515 \mathrm{p}$.

Neres, Y.X.C., Azevedo, G.T.O.S., Souza, A.M., Azevedo, G.B., Teodoro, P.E. 2019. Effect of the hydrogel incorporation on different substrates on the rooting and quality of clonal Eucalyptus seedlings. Scientia Forestalis 47: 336-345.

Noguera P., Abad M., Puchades R., Maquieira A., Noguera V. 2003. Influence of particle size on physical and chemical properties of coconut coir dust as a container medium. Communication in Soil Science and Plant Analysis 34: 593-605.

Prates, F.B.S., Veloso, H.S., Sampaio, R.A., Zuba Junior, G.R., Lopes, P.S.N., Fernandes, L.A., Maio, M.M. 2010. Crescimento de mudas de maracujazeiro-amarelo em resposta à adubação com superfosfato simples e pó de rocha. Ceres 57: 239-246.

Ramirez, P.M., Pascual-Alex, M.I. 2010. Characterization and use of a vegetable waste vermicompost as an alternative component in substrates for horticultural seedbeds. Spanish Journal of Agricultural Research 8: $1174-1182$

Schäfer, G., Souza, P.V.D., Koller, O.C., Schwarz, S.F. 2008. Physical and chemical properties of substrates to cultivate seedling of citrus rootstocks. Communications in Soil Science and Plant Analysis 39: 1067-1079.

Serrano, L.A.L., Marinato, F.A., Magiero, M., Sturm, G.M. 
2012. Produção de mudas de pimenteira-do-reino em substrato comercial fertilizado com adubo de liberação lenta. Revista Ceres 59: 512-517.

Serrano, L.A.L., Silva, C.M.M., Ogliari, J., Carvalho, A.J.C., Marinho, C.S., Detmann, E. 2006. Utilização de substrato composto por resíduos da agroindústria canavieira para produção de mudas de maracujazeiro-amarelo. Revista Brasileira de Fruticultura 28: 487-491.

Silber, A., Bar-Tal, A. 2008. Nutrition of substrate-grown plants. In: Soilless Culture: Theory and practice. Elsevier, San Diego, CA, p. 291-339.

Silva, N.M., Souza, L.G., Uchôa, T.U., Almeida, W.A., Araújo Neto, S.E., Ferreira, R.L.F. 2018. Qualidade de mudas de maracujazeiro amarelo produzidas com substratos alternativos. Agropecuária Científica do Semiárido 14: 96-102.

Silva-Matos, R.R.S., Silva Junior, G.B., Marques, A.S., Monteiro, M.L., Cavalcante, I.H.L., Osajima, J.A. 2016. New organic substrates and boron fertilizing for production of yellow passion fruit seedlings. Archives of Agronomy and Soil Science 62: 445-455.

Sousa, G.G., Novelino, J.O., Scalon, S.Q.P., Marchetti, M.E. 2011. Crescimento de mudas de maracujazeiro em função de adubação à base de boro e material de cupinzeiro. Pesquisa Agropecuária Tropical 41: 170-178.

Takoutsing, B., Tchoundjeu, Z., Degrande, A., Asaah, E., Gyau, A., Nkeumoe, F., Tsobeng, A. 2014. Assessing the Quality of Seedlings in Small-scale Nurseries in the Highlands of Cameroon: The Use of Growth Characteristics and Quality Thresholds as Indicators. Small-scale Forestry 13: 65-77.

Zavistanovicz, T.C., Araujo, M.M., Aimi, S.C., Flores, R., Berghetti, A.L.P., Deponti, G. 2017. Morphophysiological responses of llex paraguariensis seedlings to different substrates and fertilizations. Revista Brasileira de Engenharia Agrícola e Ambiental 21: 111-115.

Zorzeto, T.Q., Dechen, S.C.F., Abreu, M.F., Fernandes Junior, F. 2014. Caracterização física de substratos para plantas. Bragantia: 73: 300-311.

Conflict of Interest Statement: The authors declare that the research was conducted in the absence of any commercial or financial relationships that could be construed as a potential conflict of interest.

All the contents of this journal, except where otherwise noted, is licensed under a Creative Commons Attribution License attribuition-type BY. 